\title{
The wooden architectural complex of the city and royal residence of the John III Sobieski in Kukizów
}

\author{
Mykola Bevz \\ Department of Build Conservation; Faculty of Civil Engineering and Architecture; \\ Lublin University of Technology; Nadbystrzycka st. 40, 20-618 Lublin, Poland; \\ Department of Restoration of Architectural and Artistic Heritage; Institute of Architecture and Design; \\ Lviv Polytechnic National University; Bandera St. 12, 79013 Lviv, Ukraine; \\ m.bevz@pollub.pl; ORCID 0000-0003-1513-7045
}

\begin{abstract}
The palace in Kukizów of King of Poland John III Sobieski is known only to a narrow group of architecture and art historians. The palace and park complex ceased to exist in the 19th century. The architecture of the palace is known especially from the descriptions in the inventory documents from the early 18th century. Although the authorship of the palace design belongs to the well-known artists of the era - Augustyn Wincenty Locci and Piotr Beber, its architecture has not yet been reconstructed. A specific feature of the royal residence in Kukizów was the construction of royal buildings and town buildings in a wooden material. The intention to create a city complex and an entirely wooden residence was a unique experiment in the field of European architecture and urban planning of the 17th century. In the paper we present the results of our research on the architecture of the palace and town for the end of the 17 th century.
\end{abstract}

Keywords: royal residence, Kukizów town, John III Sobieski, palace, park, 17th century

\section{Introduction}

As Zbigniew Wójcik, the author of the book about John III Sobieski, rightly writes, the king "added splendor to his rule by building a number of monuments of both secular and sacred architecture. The most famous work of his patronage is undoubtedly the beautiful palace in Wilanów near Warsaw...” [40, p. 392]. Some of his initiatives implemented in Ruthenia and the Lublin region include the reconstruction of the castle, palace, and park in Jaworów, renovation of the castle and park in his hometown Żółkiew, the extension of the castles in Złoczów, Olesko, Pomorzany, and manors in Żółtańce, Wysock, and Pilaszkowice. In Żółkiew, the king transformed the castle buildings, added bathrooms in the park and expanded the hunting court in Garaj [21, p. 183]. He also rebuilt his tenement house on the Market Square in Lviv. It is not without reason that historians believe that the king liked his hereditary possessions the most in Rus' (Ruthenia) region - Żółkiew and Jaworów, where he most often stayed [40, p. 397-398].

This is also proved by the little-known fact of building a royal summer residence in the late 80 s of the 17 th century with a palace and garden in the town of Kukizów, near Lviv and Żółkiew. The above-mentioned objects in Rus' lands, liked and nurtured by the king, belonged to the headquarters of the elders and were rebuilt and adapted to the new needs of the royal court. The only newly built object, entirely built on behalf of the John III, was the palace complex in Kukizów. We can conventionally assume that it was the "Wilanów" in 
the Ruthenian lands (Rus' or Ruthenia - the name of the east part of the Polish state in the 14-18th century). John Sobieski's full title was - King of Poland, Grand Duke of Lithuania, Ruthenia, Prussia, Mazovia, Samogitia, Livonia and in Kyiv, Smolensk, Siversk and Czernihiv lands: Dei Gratia Rex Fidei Defensor Poloniae, Magnus dux Lithuaniae, Russiae, Prussiae, Masoviae, Samogitiae, Livoniae, Smolenscie, Kijoviae, Volhyniae, Podlachiae, Severiae, Czernichoviaeque) [17]. However, while the palace complex in Wilanów is often referred in scientific literature and recent years this object has been carefully restored together with the façades of the palace, its interiors, garden quarters, the palace complex in Kukizów ceased to exist in the 19th century and only lives in scientific literature, thanks to the few publications of historians. But, e.g., Zbigniew Wójcik [40, p. 619], the author of an excellent biography of King John III, published in 1983, when writing about the King's stays in Rus' region, unfortunately, makes no mention of his Kukizian period of life or the design and construction of a palace with a park in Kukizów. The lack of this information is also noticed on numerous websites devoted to King John III [17, 20].

\section{Analysis of previous studies}

The Kukizów royal palace is known only to a narrow group of experts in the field of history of architecture and art. Art historians who devoted attention to this are: Tadeusz Mańkowski [24, p. 133-138], Mieczysław Gębarowicz [13, p. 231-245], and in recent years Jerzy Kowalczyk [21, p. 183-189]. The first two authors reconstructed the history of the palace and its main features. Kowalczyk more precisely set the date of the palace and garden creation, narrowing down the construction for 1687-1694. He also proved the authorship of the project of Augustyn Wincenty Locci and justified that the palace was built by Piotr Beber. In his dissertation, Kowalczyk also performed a graphic reconstruction of the palace plans, based on an analysis of the inventory from 1741. Due to the fact that the palace in Kukizów did not survive to our times, Kowalczyk's work is the only and unique attempt to bring knowledge of this object in the form of planning reconstruction. It also encourages further search for information about the Kukizów residence that would complement its history, being a clue to the detailed reconstruction of architecture and urban planning. 

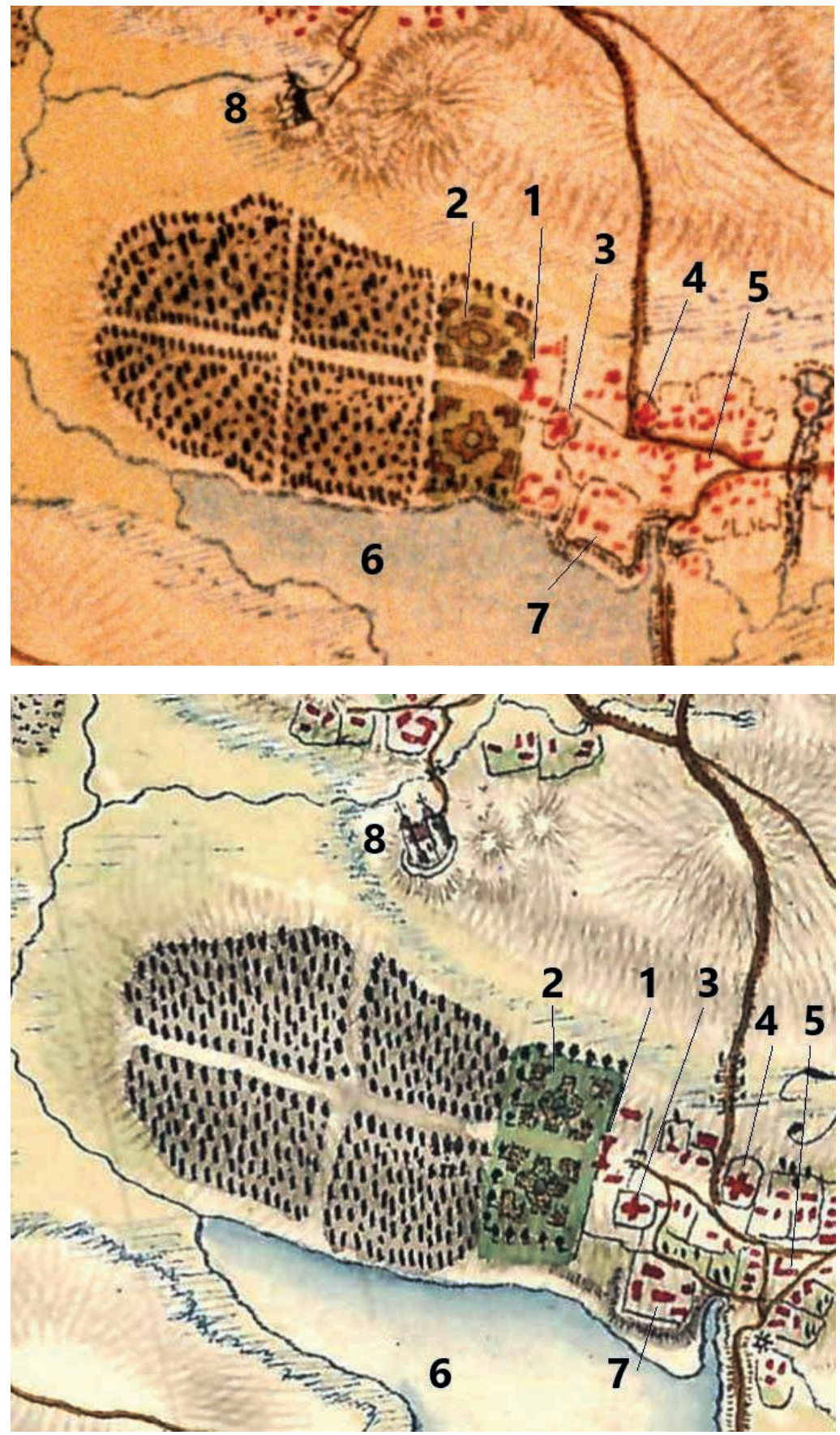

Fig. 1. The town of Kukizów on the map of F. von Mieg: A) drawing of the town plan from the period of the first map editing from 1781 (negative print; photo by the author taken in Kriegsarchiv in Vienna) [26]; B) drawing of the city map from the period of the second map editing (so-called "fair copy" of the map) from 1782 (from the internet publication of the map on the "The Mapire.eu" website [25]). Numbers indicate: 1 - palace, 2 - park, 3 - wooden Greek Catholic church, 4 - wooden Catholic church, 5 - Market Square with a wooden town hall, 6 - lake, 7 - old castle, 8 - wooden church in the village of Remeniv 
Archival information about the palace complex in Kukizów is very poor. In the Lviv archives, materials regarding the town's history have been preserved, but unfortunately there are no documents about the royal residence. The most important source remains the inventory of the palace and garden from 1741, from the archive in Warsaw (published by M. Gębarowicz [13, p. 231-245]). A new, very important source for clarifying the location of the palace and recreating the complex planning system was the map of Friedrich von Mieg, made in 1779-1782, and kept in the military archive in Vienna. Although the map was made by hand in a scale of 1:28800, Kukizów is drawn on it with extreme precision [26]. Based on the map analysis, the complex plan reconstruction was successfully completed and published in 2006 [10, p. 64-65]. Major analyses of the palace and town were made in our publication in 2016 [11].

\section{Purpose of the paper}

In this work, we try to recreate the planning and spatial structure of the Kukizów town during the construction of the royal residence and determine the exact location of the palace by reconstructing the complex planning system of the residence with the park and fortifications. It needs to be pointed out that there was no single building (palace) in Kukizów. An unique architectural and urban complex, characteristic of the Baroque era, was created. Studies on the urban context of the residence have not yet been carried out. The issues of linking the palace with the garden and fortifications are not fully displayed.

\section{Presentation of research results}

Professor J.Kowalczyk tried to determine the hypothetical location of the palace and garden on the basis of the cadastral map from 1854 [21, p. 188]. It should be noted that this map shows the small remains of the former complex (fragment of the garden without the palace) after its major transformations in the 18th and the early 19th century. Our field research and observation of small traces of palace foundations allowed for a more accurate indication of its location.

To reconstruct the planning structure of the royal residence built at the end of the 17 th century in Kukizów, we must first analyze the conditions of its creation and the earlier nature of the settlement, answering the questions of what the motivation was for choosing the site of the palace and park complex and how its surroundings were shaped.

\subsection{Reconstruction of earlier development stages of Kukizów}

The Kukizów urban development is divided into several individual phases.

\subsubsection{The first phase, dated to the 15th century, when the settlement and a small castle were located here}

The first mention of the Kukizów town was recorded in December 1440, in the record of the postponement of the court case about the ownership of the pond in Kukizów between Stefan and John (Stephanus, Iohannes) from Lviv and Gregorius (Georgium de Kukyziv) from Kukizów [5, ark. 44]. The information about the pond is very important. The pond and the picturesque surroundings were later factors shaping the town's development.

The name was given from the surname Kukiz, which may have oriental linguistic origins (Turkish-Tatar) [18]. Karaite origin cannot be excluded: "kok" - blue, "koz" - eye 
[9, p. 336-337]. The owners of the settlement were the Kukizowski family, and the above-mentioned Gregorius from Kukizów - its representative [5, p. 19].

\subsubsection{The second phase can be dated to the 16th-17th century}

Already at the end of the 15th century, the village belonged to the Herburt family [8, p. 606], who bought it from the Kukizowski family [33, p. 176]. In 1502, Aleksander Jagiellończyk as a reward for the faithful service of Frederick of Kniehinicz (de Knyahunicze) Herburt, transferred the village from Polish and Ruthenian law to the Magdeburg law [8, p. 854]. According to the author's hypothesis, the Herburt castle (on a square plan with semicircular bastions or towers in the corners) was located in the southwestern part of the downtown, in today's "tower". It was probably built at the end of the 15 th or the beginning of the 16th century on a small hill above the pond on the town's border.

To this day, older residents of Kukizów remember the toponym "tower", which they call the territory to the left of the road, at the entrance to the city through a dam on the pond (near the mill). The remains of the fortifications were leveled after World War II [41, p. 500]. We have no doubt that the remains of the tower (or towers) of the older castle were called so. Confirmation of oral tradition can be found on the map of F. von Miega from 1779, where between the downtown and the pond, quite carefully, traces of earth embankments after two towers or bastions (Fig. 1a) [26] were drawn.

Traces of one more manor (or small castle) were identified outside the city (fig. 2), in the western part of the settlement - on an artificial island, in the middle of a large pond, in the "castle", at the small settlement in Leszcziw (Leszczów). The castle was located on an area increased by 3-4 $\mathrm{m}$ above the pond, on an island with a diameter of about 100-125 m (fig. 2). It was surrounded by a ring of rampart and ditch (still partially preserved to this day) among the wide, swampy valley of the Remenowski Potok River. From north to southwest, this valley was cut by a dam, which served as an entrance road to the castle. Its relics are preserved to this day. The object itself was found on a map from 1890 (Fig. 3) [22]. The artificial islet with a rampart and moat was leveled in the 1980s as a part of the agricultural work of the local kolkhoz. Quite recently, this place was entered into the provincial register of archaeological monuments as a "late medieval castle" [35, p. 56]. 


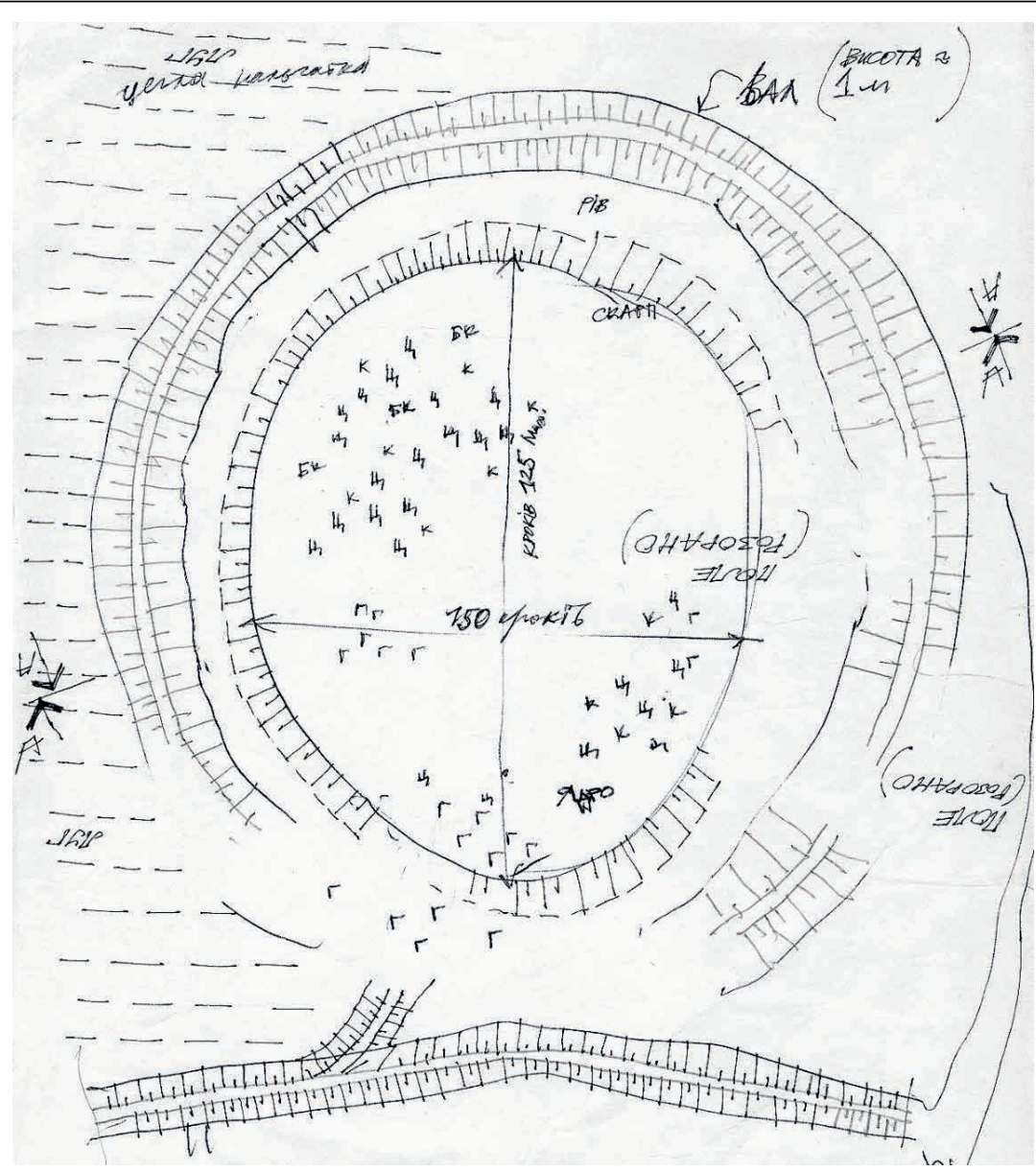

\section{Section A - A}

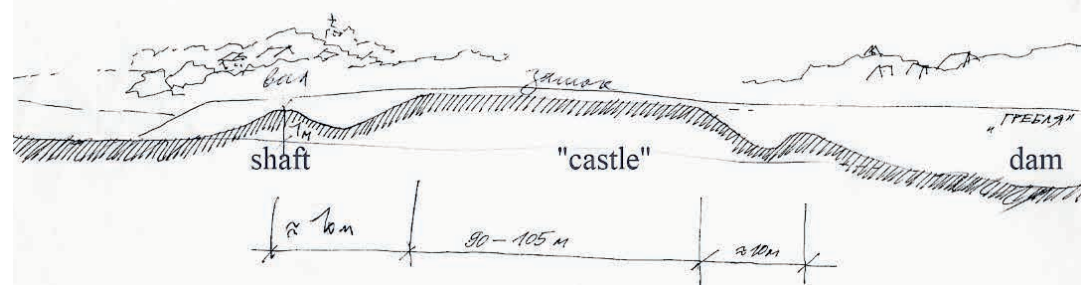

B

Fig. 2. Field survey of the place of the old castle in Kukizów in the valley of the river Remeniv Potik. M.Bevz, 1986. The object is freshly tilled. Remains of shafts, moats and dam were fixed. Many fragments of Gothic bricks, including profiled, were found. The inner diameter of the complex is 100x125 m. B - Section A-A. Field survey of the place of the old castle in Kukizów, 1986. M.Bevz. 
As part of the field reconnaissance, a significant amount of archaeological material was collected from the surface. First of all, the finger-bricks of various sizes were found, as well as profiled gothic bricks (which can be testified to the building from the 14th-16th century), remains of stove tiles and pottery, metal objects, fragments of stained glass with a diameter of $8.5 \mathrm{~cm}$, and a ball stone with a diameter of $10-12 \mathrm{~cm}$. Historians and conservators date this material from the 15 th to the 17 th century [2, p. 1-8]. The oldest unwashed tiles have gothic features. Some ceramics probably come from the ceramic center in Potylicz. A huge heap of bricks testifies to the existence of brick buildings here in the past.

The small castle on the island was probably built by the Herburts (as evidenced by dating some archaeological materials) and used as a hunting lodge.

After 1502, when Kukizów moved from Polish and Ruthenian law to the Magdeburg law, the city began to transform from a rural settlement to an urban type. There was a market square and a regular street plan, fortifications (downtown defense shaft from the west and east, with a moat dug) and three gates. The privilege confirming the town rights from 1538 of Zygmunt I Old also introduced a weekly market and two fairs a year [8, p. 607]. The city's coat of arms was a key on a red background, symbolizing the key of St. Peter.

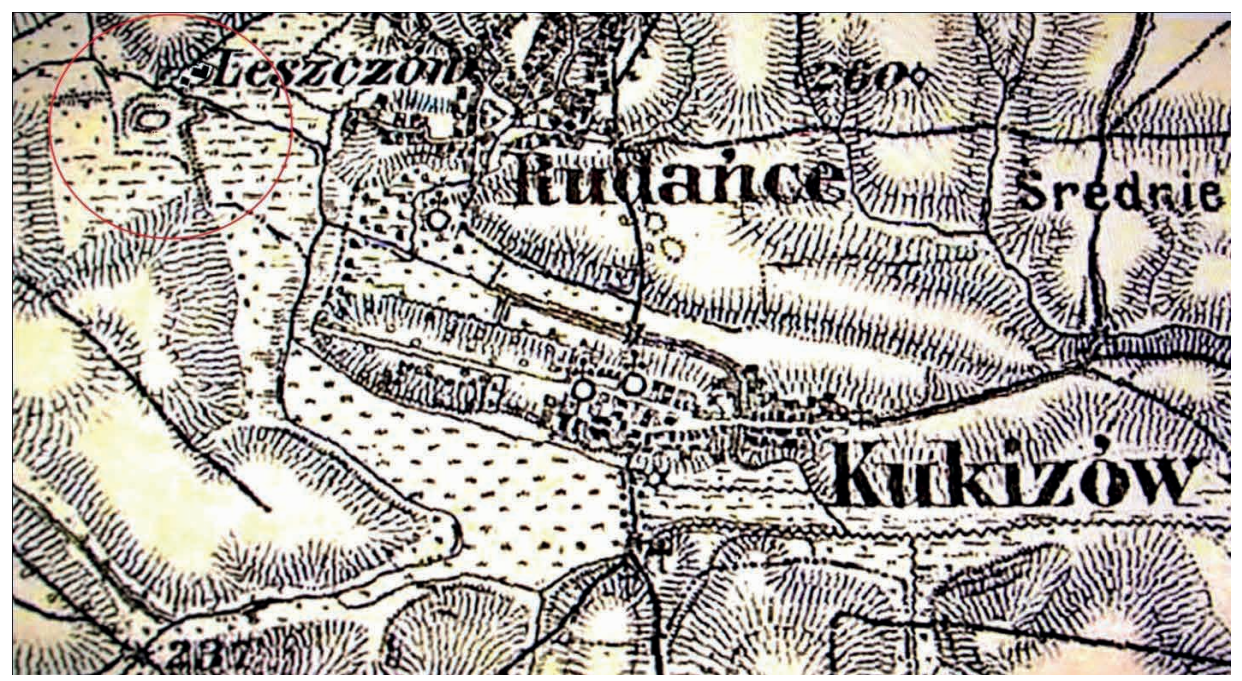

Fig. 3. A fragment of the map of 1890 with a castle near the Leszczów forest (Kriegsarchiv Wien. H 76-133, F. Map of 1890 of Galicia [22])

At the turn of the 16th and 17th century, Kukizów became the property of the hetman Stanisław Żółkiewski. In the erection act of the church in Żółkiew of January 12, 1623, Jan Żółkiewski defines himself as "heir in Żółkiew, Jaryczów, Nahaczów, Dziedziłów, Kukizów..." [4, p. 213]. After the death of the son of the hetman, the goods went to the daughter Zofia, and then to her granddaughter Teofila, who married Jakub Sobieski. John III Sobieski inherited the town from his mother [13, p. 231]. He made the town his residence and built a palace, which was finished in 1690 [21, p. 184-185]. After him, the son Konstanty took over and renewed the Magdeburg rights (privilege of May 20, 1699) [3, p. 113]. In this document, Kukizów was also called the Krasny Ostrów. After the death of Konstanty, Kukizów fell to the eldest son of John Sobieski, Jakub. In 1740, his daughter Maria Karolina sold the town to Michał Radziwiłł [20, 18]. 
The mention of the existence of a orthodox church in Kukizów from 1560 is noted in the document regarding the donation of the processional cross of artistic work by a shoemaker from Żółkiew [34, p. 77-108]. An independent Catholic parish was established in Kukizów before 1600. The date of establishment is unknown. The first church was to be very modest, without any foundation [19]. In the Sobieski era, a Karaim colony was established in Kukizów, consisting of five families brought from Troki [7, p. 26-28], which had their kenasa (synagogue) here [16].

\subsubsection{The third phase of the town's development is dated to the second half of the 17 th and the beginning of the 18th century}

The next, most interesting from the urban point of view, stage of city development is associated with the Sobieski family. We can assume that John III Sobieski was attracted to this place because of the picturesque location and good hunting conditions. The swampy valley of the river flowing from Kulików, with numerous bends, was an ideal place for hunting wild birds. The presence of an old hunting castle next to a large pond and a small forest increased the attractiveness of the place. Located near Żółkiew and Lviv, the wooden town was perfect for a summer stay and rest in the countryside. There is no doubt that the older downtown castle and Herburt's hunting castle were used by Sobieski for this purpose, although they were small and outdated buildings, not really suitable for the new needs. The requirements of running the royal court necessitated the design of a new residence. Its architecture, taking into account the character of the town, was to be made of the traditional material (wood), but made in a modern style, combined in a compositional way with the town's buildings and blended into the park.

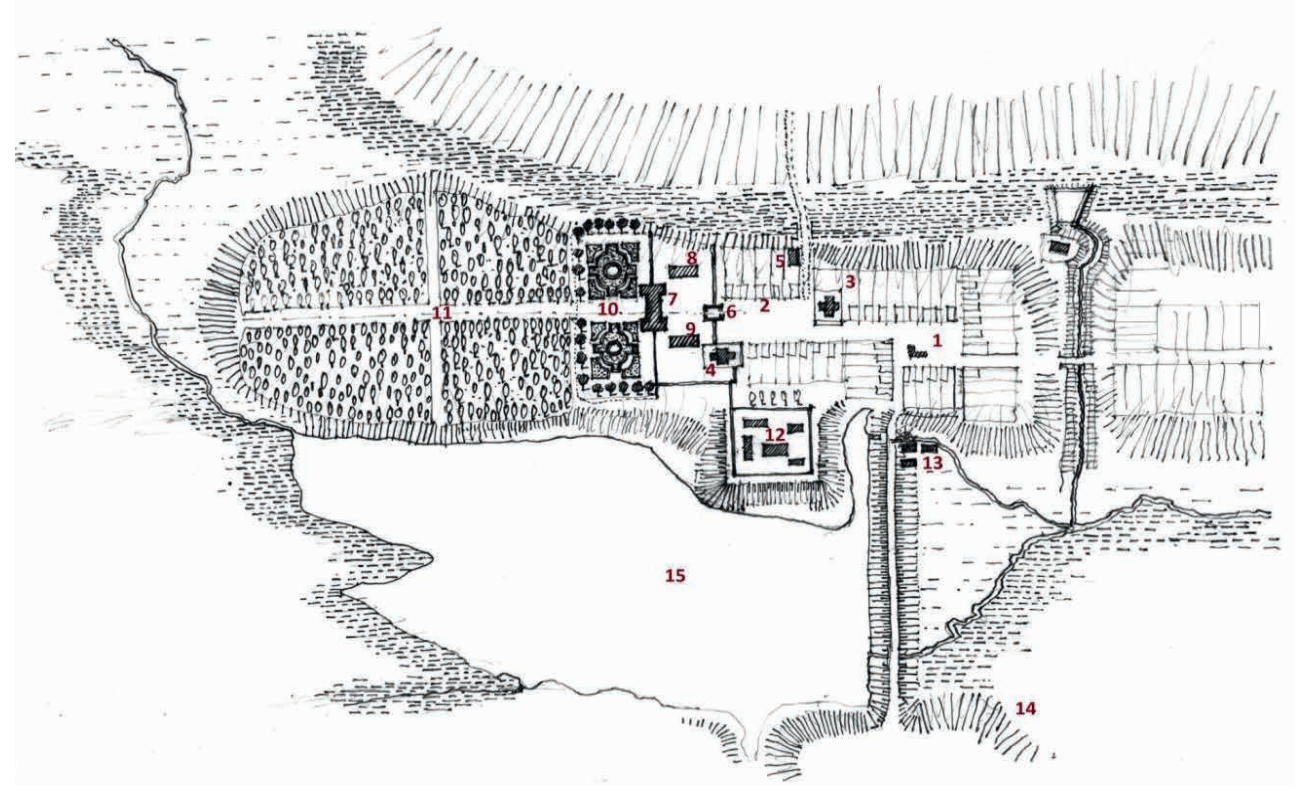

Fig. 4. Preliminary reconstruction of the planning and functional structure of Kukizów from the second half of the 18th century based on the analysis of the original "fair copy" of the F. von Mieg map from 1782: 1 - market square with the town hall; 2 - square-esplanade in front of the royal residence; 3 -Roman Catholic church; 4 - Greek Catholic church of St. Nicholas; 5 - brickyard; 6 - entrance gate to the former residence; 7 - palace; 8 - kitchen; 9 - chancellery; 10 - one-story bed garden; 11 - walking sticks; 12 - court buildings at the site of the older castle; 13 - mill; 14 - Karaim cemetery; 15 - pond (author Mykola Bevz, 1996 [10, p. 150]) 
After the decision to build a summer residence in Kukizów was made, preparatory and design work began. The concept envisaged the creation of a new palace and park complex in the western part of the city, next to the downtown and the old castle. The design of the new complex, according to Mieczysław Gębarowicz, was initially made by the famous Dutch architect Tylman of Gameren [13, p. 232]. The architect's archives included designs of wooden palaces, one of them signed as "the design of a multi-story wooden manor for the king" $[28$, p. 274]. Thus, the version about the participation of Tylman of Gameren in the birth of the idea of architecture of the new wooden palace of John III Sobieski may be true. How the project was played out is unfortunately not known. Eleven drawings of the aforementioned Tylman's project were lost during World War II, so we cannot connect and compare design decisions with the urban and topographic situation in Kukizów.

Jerzy Kowalczyk proved that the design of the palace was created with the participation of the architect Augustyn Locci, who is described as the author of the design in documents created during the construction of the building [21, p. 182]. The builder of the palace is Piotr Beber - the architect who realised most of the royal buildings in Rus, the author of, among others, the extension of the town hall tower in Kraków, the Korniakta tower in Lviv, the town hall and synagogue in Żółkiew, the castle in Nowy Jaryczów and others [27, p. 397]. The construction of the palace lasted until 1693. Then the park was designed (in Italian style?) and the town was tidied up. It was also mentioned that the king himself was directly involved in the work next to the gardener [21, p. 234].

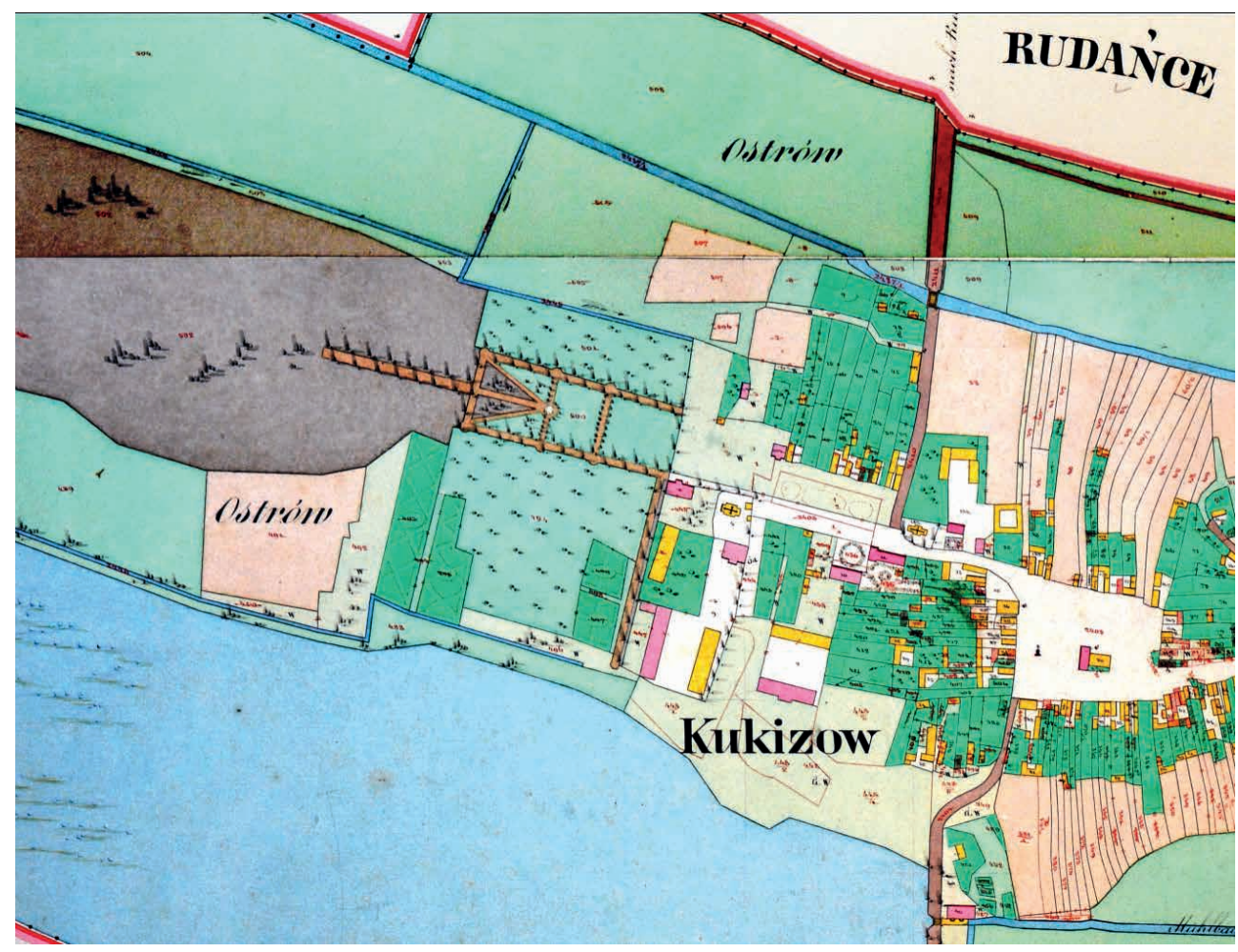

Fig. 5. Kukizów on the cadastral map from 1854 (Tsentralnyi Derzhawnyi istorycznyi archiv Ukrainy v misti Lvovi, Fond 186, opys 5, sprava 330. - Kukyziv. Kadastrova karta, 1854. - Ark. 3, 8 [36]) 


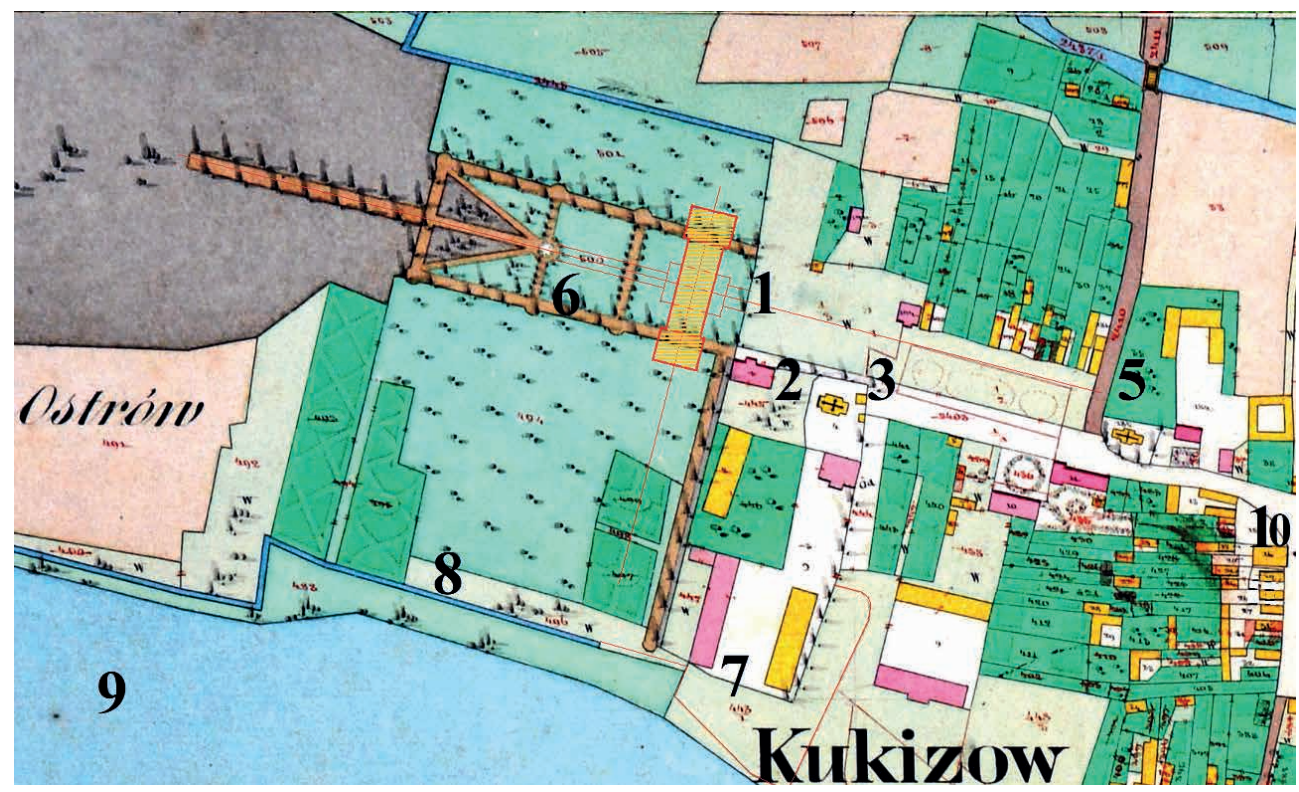

Fig. 6. Hypothetical reconstruction of the palace location on the base of the cadastral map of Kukizów from 1854: 1 - the hypothetical place of the palace; building configuration; 2 - the building of former chancellery; 3 - Greek Catholic church; 4 - the building of former kitchen; 5 -the Catholic church; 6 - park; 7 - remains of south bastion; 8 - the canal; 9 -the lake; 10 - the building of kenasa

According to the inventory of June 20,1741, the park occupied an area of approximately 17,000 square fathoms $\left(62,000 \mathrm{~m}^{2}\right)$. Part of the park was planned in a regular-quarters style (there were rows of clipped plantings, there were a large number of medicinal plants, a special gardener's house was built) [21, p. 234]. It is assumed that the second part of the park was shaped in the form of alleys marked out in the existing forest, so that its natural environment can be included in the garden. The main garden avenue also cut west through the forest and lengthened towards the castle on the pond by a long wooden bridge made of oak piles. Remains of piles were removed after World War II, after the liquidation of the pond [29, p. 78]. 


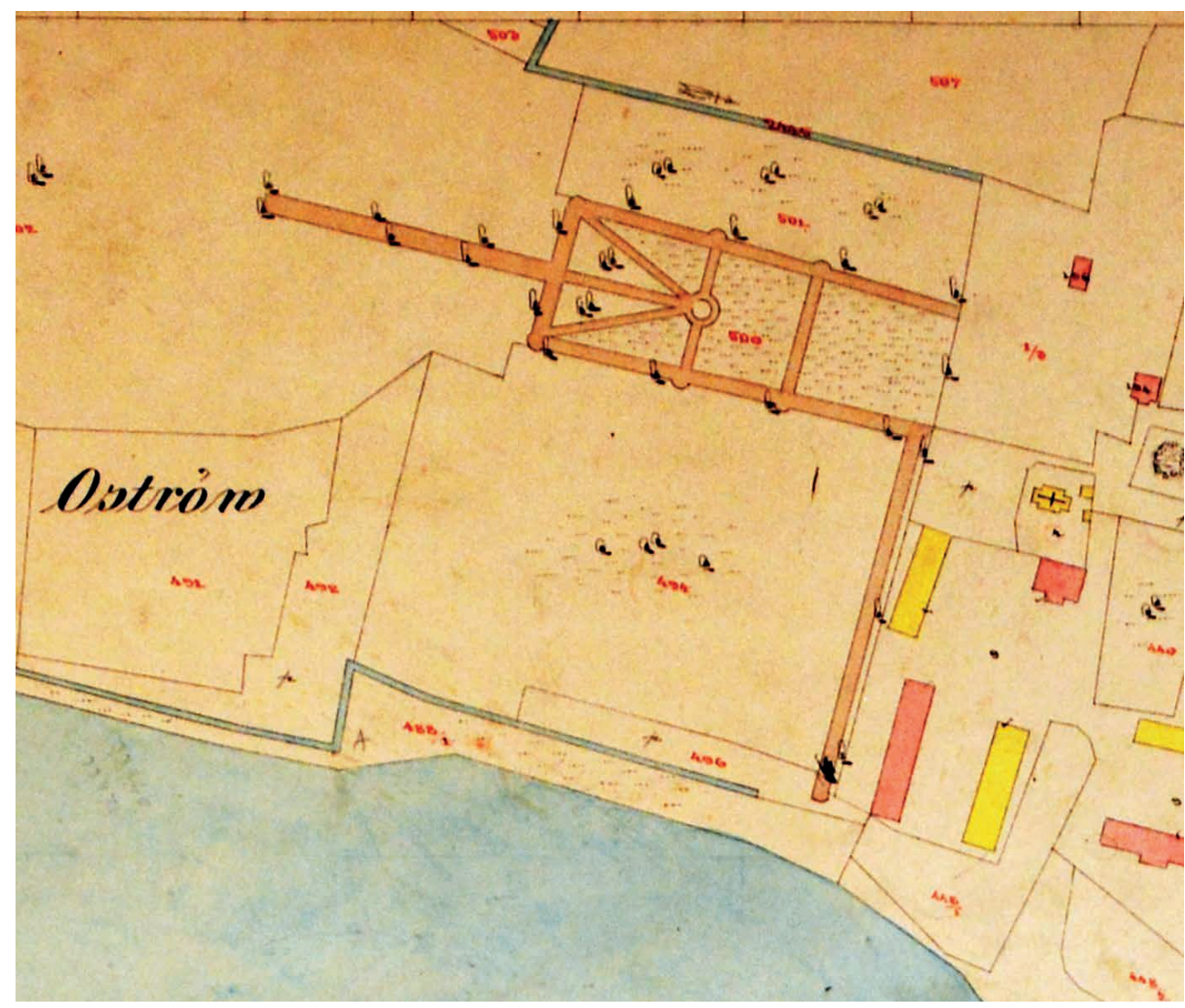

Fig. 7. Kukizów on the cadastral map from 1870 (Tsentralnyi Derzhawnyi istorycznyi archiv Ukrainy v misti Lvovi, Fond 186, opys 5, sprava 331. - Kukyziv. Kadastrova karta, 1870. - Ark. 8) [37]

The palace was located in the western part of Kukizów, behind the ukrainian church grounds (Fig. 5, 6, 7), on the border with the downtown area. The complex of residence was also built: kitchen, granary, bakery, basement, barn, dock at the pond, as well as the building of chancellery [21, p. 244].

The name "Zwierzyniec" was also found mentioned in archival documents (referred to in the letter-request of the townsmen of Kukizów to C.K. Governor of October 29, 1814) [29, p. 103-104]. Although the case concerns a dispute from the beginning of the 19th century, this mention is considered to be an important fact, indicating the existence of a zoo in the royal park in the past. Knowing King John III's preference for hunting, it can be undoubtedly said that the introduction of the zoo took place in parallel with the establishment of the park. At the beginning of the 20th century, the area above the pasture was referred to as "the pond" (on the cadastral map of 1854 this place above the pond is marked as islat - "Ostrów”) (Fig. 5, 6, 7). 


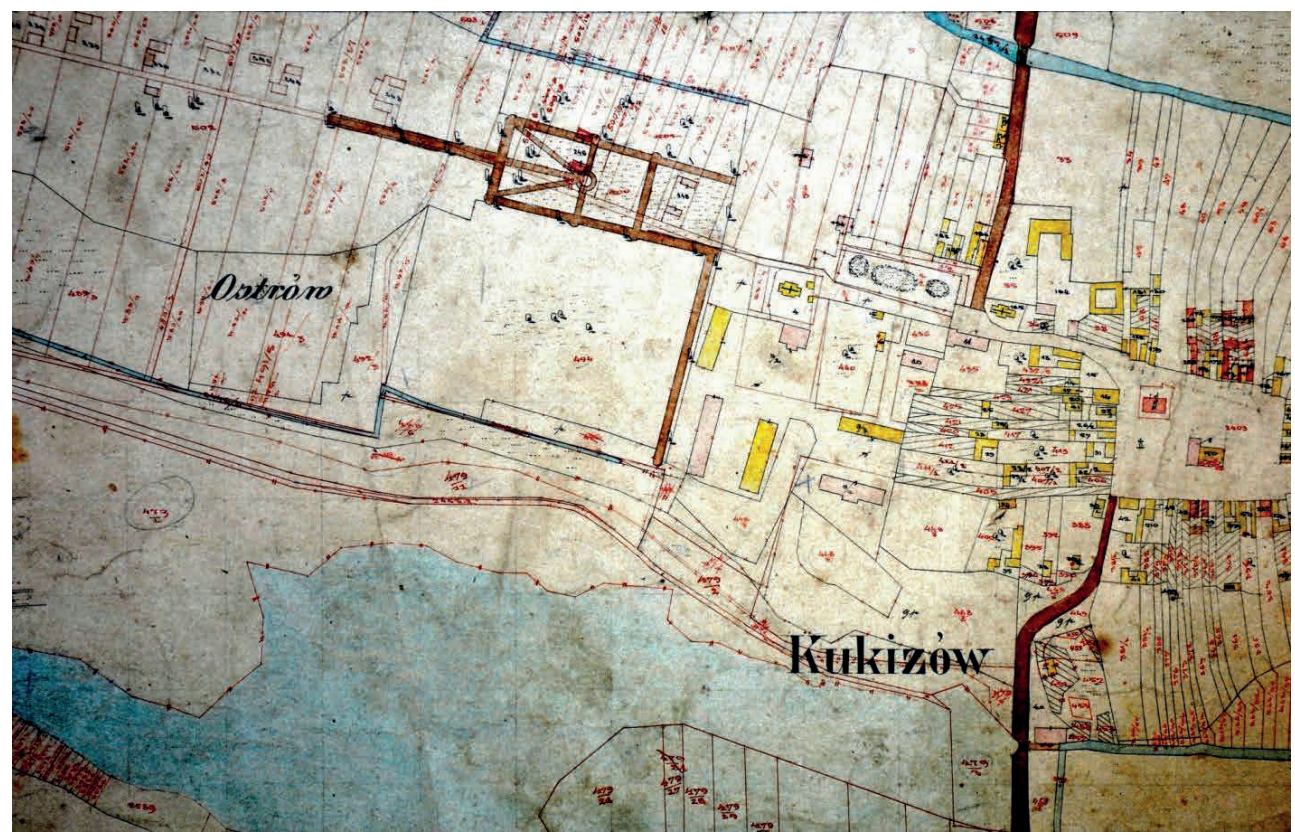

Fig. 8. Kukizów on the cadastral map from 1927 (Tsentralnyi Derzhawnyi istorycznyi archiv Ukrainy v misti Lvovi, Fond 186, opys 5, sprava 335. - Kukyziv. Kadastrova karta, 1927. - Ark. 8 [38])

\subsection{Hypothetical reconstruction of the architecture of the Royal Palace}

Art historian Jerzy Kowalczyk presented the reconstruction of the palace plan (based on the reading and interpretation of the palace inventory from 1741) as a rectangular building with a six-column portico in the main eastern facade (Fig. 9). The palace was extended on the north-south line [21, p. 184-185]. a newer version can be sketched, specifying the general scheme of the palace plan, combining Kowalczyk's concept with the analysis of the palace plan on the map of F. von Mieg and cadastral maps of Kukizów from 1854, 1890 and 1927 $[15,26,36,37,38,39]$. According to the drawing on the map, it can be concluded that the palace as an elongated rectangular in the plan, had two projections on its sides (where, as we know, there were offices: the king in the south and the queen in the northern part, alcove on the first floor and wardrobes on the ground floor).

Figures 10a and 10b present the author's version of the reconstruction of the palace plan. projections are added protruding beyond the façade line on the main and garden facades from the plan of F. von Mieg (Fig 1a). The presence of projections also results from the palace's descriptions in the inventory from 1741, where it was noted that in the corners of the roofed floor there were helmets covered with sheet metal with pinnacles made of wood and white metal. The architectural solution of helmets in the corners of such a small palace was exceptionally possible with the existence of projections, when the helmet structure protruded outside from the main body of the roof. In a letter of August 29, 1690, of Piotr Beber, the builder of the palace, to Andrzej Wolski, writer of the goods of Żółkiew [21, p. 184], he talks about the crowning of the four corner cabinets with "pinnacles with tin knobs and wooden elements, which are to be made by the carpenter according to the model prepared by Beber". 
The author's version of the palace plan develops slightly the hypothesis of Jerzy Kowalczyk (compare Fig. 9 and 10). The difference is mainly in adding projections. The second important factor is the length of the building. Based on Mieg's map, the plan is reconstructed in different proportions - the building is longer and each room has a square plan (which was characteristic of a wooden building). Inside the building there was the gallery-balcony, which surrounds the great hall at the height of the second floor; it had a rounded plan. The six-column portico supported on the main and garden façades was, in the author's opinion, two stories high and crowned with a triangular gable (Fig. 10, Fig. 11).

After the palace was built in 1693, works on decorating its facade continued for some time, as well as the construction of the gate, walls around the residence, buildings "for the convenience of the court" and the garden [21, p. 185].

The palace was decorated with the participation of a German stucco master (sculptor?) sent from Warsaw [6, p. 33]. His participation in the works was noted in letters to Andrzej Wolski from 1696. The artistic decoration of the palace was also made by master Tymofij. In 1690 he came to Kukizów after being paid from the castle cash in Żółkiew for the paper "for painting abrasions to Kukizów" [6, p. 60]. It can be assumed that these were palace interior decoration designs.
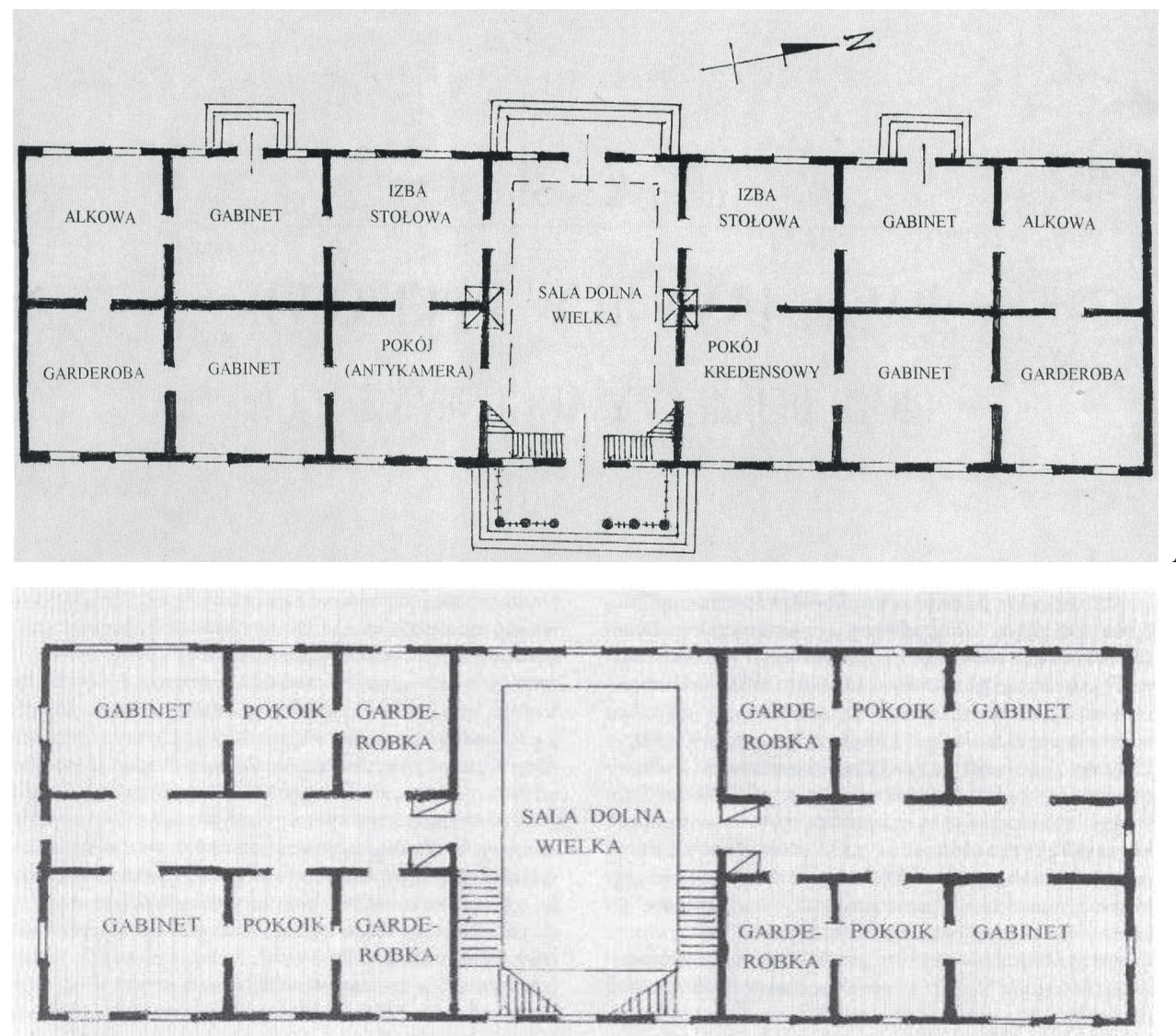

Fig. 9. A, B - Hypothetical reconstruction of the planning structure of the palace of John III Sobieski in Kukizów by J. Kowalczyk (Kowalczyk J. Pałac Jana III w Kukizowie: Piotr Beber czy Augustyn Locci? // Arx Felicitatis. - 2001. - S. 183-189 [21]) 
Mieczysław Gębarowicz believes that painting works in the newly built wooden Kukizów residence began in June 1690 [13, p. 245-247]. An unknown group of contractors took part in the works. Piotr Poznański and Udnowski [6, p. 61], as well as journeyman Karaim, were mentioned in the accounting books, without giving his name. In 1692, the painter Tymofij worked on ceiling decorations [6, p. 61]. It is known from the inventory of 1741 about the ceiling painted on canvas in the king's bedroom (in the alcove) and in the table room, where it was painted on plaster ("alfresco") [13, p. 237]. The note of August 29, 1695 gives information about "a painter devoted to master Tymofij, how to paint on the headliners in the Kukizów palace, sent in a tin box from Warsaw" [6, p. 61].

The palace was built using special technology of wood cut to the format of a brick and bonded on a lime mortar (like the bathrooms in Żółkiew). From the outside, the walls were painted red, imitating a "brick thread" [13, p. 238].

In summary, drawing information from various sources, here is an attempt to recreate the image and calendar of the royal residence.

Palace: a two-story building with a third floor hidden in the roof; tops of four corner cabinets with pinnacles and wooden elements (according to the Beber's model); large windows on the ground floor and smaller on the first floor, with fittings and shutters; the size of the glass is different (French windows in the royal apartments); in 1692, 460 straight glass panes were prepared for the palace; inside, works completed in 1693; in 1694, the outside walls were still in a raw state, without developing the facade; the work outside was not completed during the king's life (1696); inside there were furnaces from the workshop in Sieniawa (the order of John III to make tiles by craftsmen of the pottery guild in Sieniawa dates back to 1693 [23, p. 114])); the palace architecturally beautiful and unusual; in 1711 one side of the palace (main) was ready in terms of both painting and woodcarving; in 1739, interior decorations (paintings and goldsmiths) were led by Antonio Castelli (for the new owner - Gozdzki) with the participation of Bazyli Petranowicz.

In November 1693, the king personally, accompanied by the architect, measured the location of the gate and other buildings for the convenience of the manor [24, p. 137]. These facilities were to be built quickly, within one season. 


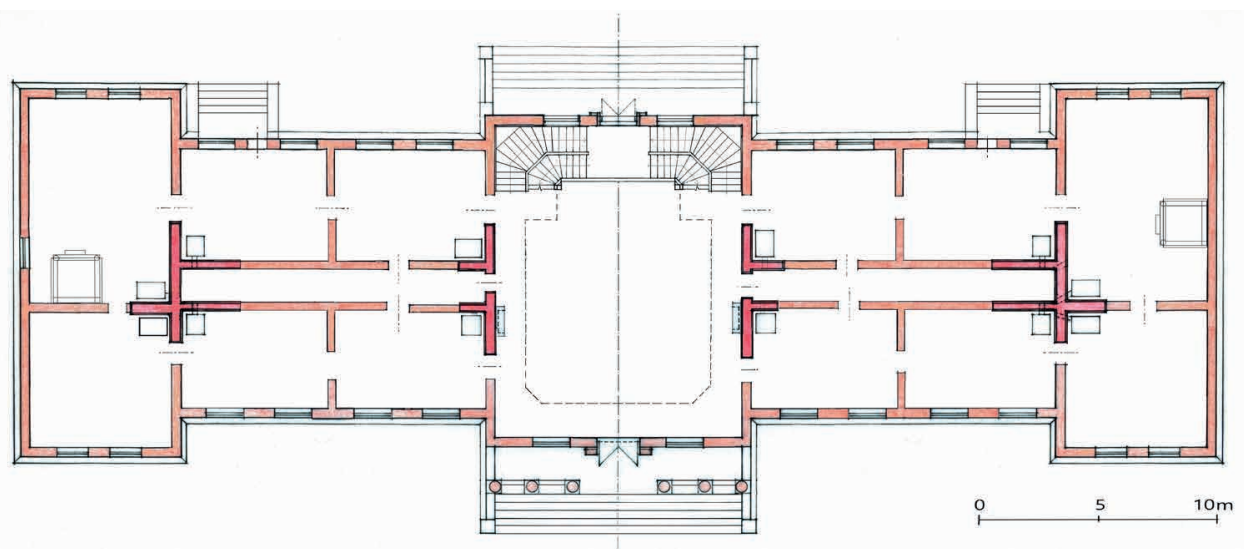

A

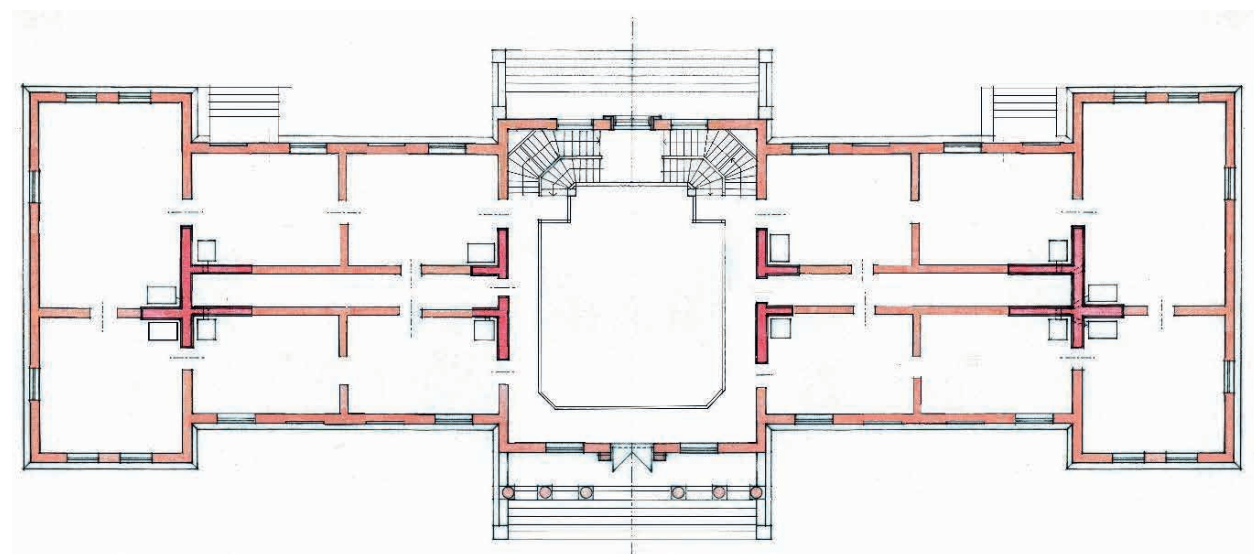

Fig. 10. A hypothetical reconstruction of planning structure of the palace of John III Sobieski in Kukizów for the period from the end of the 17th century made based on analyzes of the original $1781 \mathrm{~F}$. fon Mieg map and the cadastral map from 1854 (Mykola Bevz, 2019): a) parter; b) the first floor

In the inventory from 1741, on the occasion of the writing of a lease contract by Gozdzki, the object was described as follows:

- the palace built of wood;

- the palace has the three-story form (third floor fused into the attic);

- the plan of the story - is the arrangement on a mirror principle (plans illustrated by J. Kowalczyk; Fig. 9a, b) and our version (Fig. 10a, b);

- the palace has the six-column portico on the axis of the main and rear elevations; the entrance on the main facade has a carved portal;

- a two-story floor is in the center of the building; above the first floor there is a second one in the attic;

- a large upper hall with seven windows is above the lower hall; next to is a confectionery with three windows and four doors;

- corner upper offices topped with a roof with domes (helmets); 
- dormers in the roof with two windows;

- shingled roof;

- the palace has a regularly divided façades: in the front facade 17 axes of windows (and doors) and 19 in the garden facade;

- windows for two and four quarters each; lower windows on the first floor;

- facades decorated with pilasters;

- the corners of the palace enclosed in wooden rust decoration "ad instar hewn stones" $[13$, p. 242] (one vertical row on the ground floor had 14 tiles; in total there were $505)$

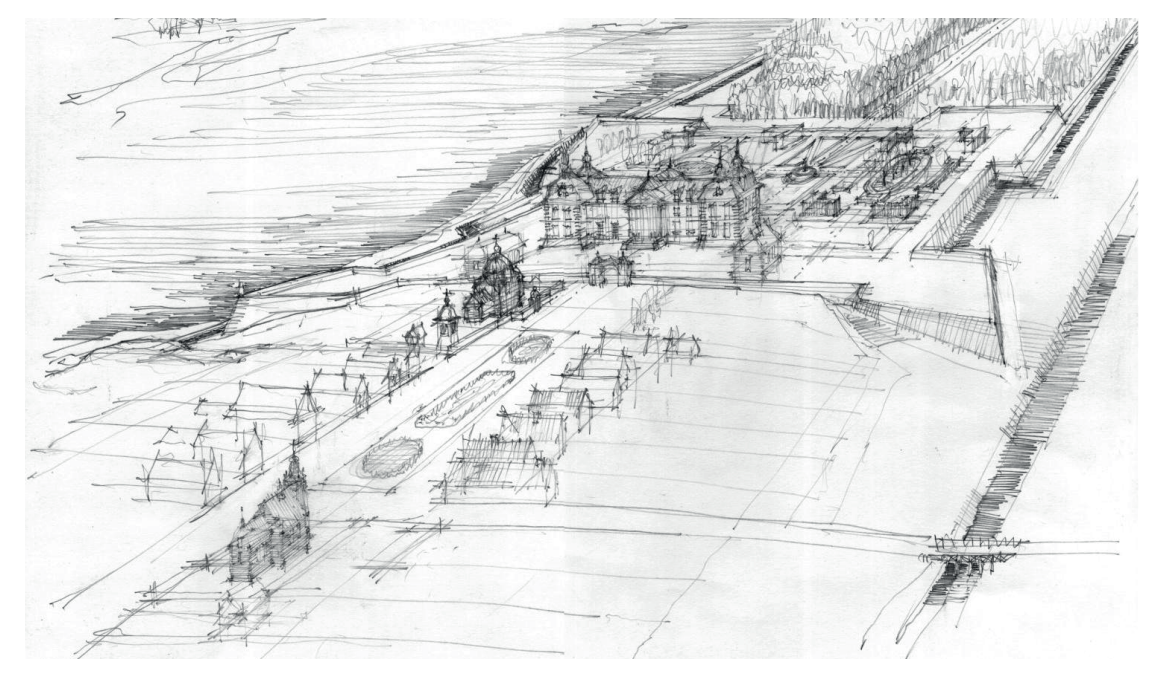

Fig. 11. A hypothetical reconstruction of the palace and park complex of John III Sobieski in Kukizów for the period from the end of the 17th century, aerial drawing (by Mykola Bevz, 2014)

- to give the building the appearance of a brick building, the palace was painted red, "in a brick" [13, p. 242] (on a plaster base?);

- portico in the facade on six columns, between which there are banisters, above the door the "texture of wood carving work" (lintels carved, profiled, decorated with cartouches and figurines of carved melons);

- Sculpture decoration "Melusine holding the shield with gilded crown" [13, p. 242] is on the façade from the side of the garden above the central door;

- "domes covered with white sheet metal and four iron studs with white metal shields on four corner cabinets " $[13$, p. 242] above the first floor; the rooftops on the corners of the building differed from the roof of the body; the corner tops had not a mansard broken form with shingle sheathing, but were made in the form of a helmet and covered by white (zinc) sheet; each helmet was finished with a needle iron pinnacle, to which a zinc shield (painted and gilded?) was attached - the Sobieski's family emblem);

- the palace built on a brick pedestal (with a basement in the north-east corner from the side of the kitchen). 
In 1840 , the palace ceased to exist. Its iconography is unknown. After the finish of the palace build, the park was founded (in Italian style) and the town was cleaned up. In cooperation with the gardener, the king himself took part in the works [13, p. 234].

Garden: after the Kukizów acquisition in 1810, Gerwazy Strzelecki describes the garden (the palace does not exist) as follows: the "Lord's garden" at the pond (new) and the "Italian garden from Fossa" (royal) [21, p. 189]:

- the gardens covered an area of around 17,000 square fathoms (62,000 m2); new garden $-1 / 6$ of the area; part of the royal park in the style of regular housing [13, p. 234], part in the form of a forest with marked paths (fig. 12);

- not very extensive assumption, limited from the west with a "thrust" or defensive fortifications (?); the entrance to the garden led from Ostrów through a drawbridge;

- axial composition: a central alley and two parallel sides, between which linden coolers (cabinets) were located in the corners and four of them - in the middle "with sofas and a marble table";

- terrace garden, with turf stairs;

- quarters surrounded by boxwood and filled with 'various herbs';

- fruit trees between the quarters and on the sides of the garden [13, p. 244-245].

Jerzy Kowalczyk believes that the garden designer was Jakub Kochanowicz - administrator of the royal gardens in Ruthenian estates in the years 1681-1688 [21, p. 188]. A gardener's house was built in the park, as well as the abovementioned economic facilities of the residence.

The planning structure of the city during the existence of the royal residence consisted of two main parts connected to each other: a palace and park complex with a ring of bastion fortifications and downtown with a market square in the center. The panorama of the town next to the palace is dominated by the silhouettes of three temples: the church, the Orthodox church, and the Karaim kenasa. The downtown consisted of a market square with a wooden town hall and three main streets (Fig. 12). The city had its fortifications, and thanks to its excellent location on the hill, it was surrounded by water on all sides.

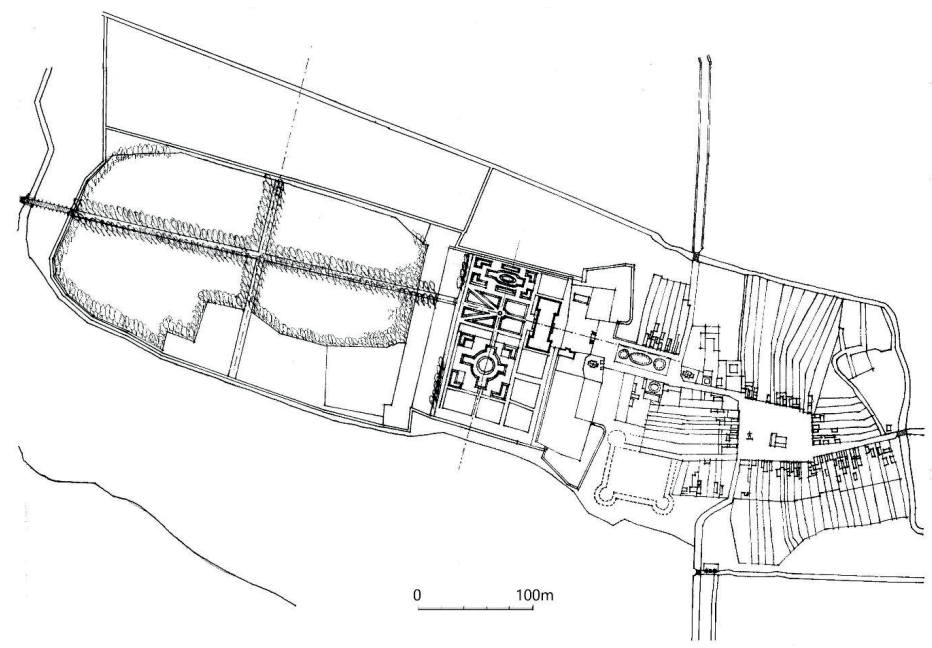

Fig. 12. Reconstruction of the planning structure of the town, palace and park complex of John III Sobieski in Kukizów; author's version, drawing by Mykola Bevz 
A wide esplanade led to the residence from the market, which was a continuation of the street from the northwest corner of the square. The composition of the esplanade was oriented on the main axis of the palace building. In the eastern and southern spans of the esplanade buildings, wooden buildings of the church and orthodox church appeared as dominants.

Reconstructing the old planning scheme of the palace complex of the John III Sobieski, let's analyze the historical maps of Kukizów. At first glance, the park plan presented on the cadastral map from 1854 does not agree with the previous plan on the map of F. von Mieg (Fig. 1 and 6). It also does not correspond with historical descriptions of the park from the time immediately after John III Sobieski (from the 1741 inventory).

The map of F. von Mieg was made in two editorial versions [32, p. 18], which differ partly in content. In the context of the presentation of Kukizów's plan, they should be analyzed as the original and a copy (fair copy) of the map, made between 1779 and 1782 (Fig. 1a and 1b). The copy is poorer with important details. The original drawing (Fig. 1a) shows in more detail the old Herburt castle, which was located by the pond at the entrance to the town from Lviv.

The monastery buildings on the former bastion, south of the church (they were drawn on the copy) were shown precisely. The market square was drawn more accurately in the form of a square (the copy of the market square is irregular). On the first and second versions of the map, the plans of the palace gardens are fundamentally different. On the original, two-quarters of the garden are drawn in different sizes. The southern section is larger, square in plan, with a cross flower bed in the center. The northern, however, smaller, rectangular, has the form of an oval flower bed, cut off, without wings. These right and left parts that vary in size, as well as the clear asymmetry of the garden plan concerning the main avenue, also appear on the cadastral map from 1854.

On the newer version of the map of F. von Mieg, the garden plan has been "improved" and drawn as the symmetrical layout with even quarters. Of course, there is a situation when in the first version the unknown author sketched the plan of the palace and park foundation by nature, passing on correctly perceived details, and in the second version (made based on the first, in cozy conditions) the second author mistakenly "improved" the configuration of the garden quarters for more regular and symmetrical.

The plan of the palace on the map of F. von Mieg was drawn very precisely - in a rectangular form with four corner projections. We can even approximate the proportions of his plan. The border of the manor and its fence was shown. From later photos of the church, published by Yaroslaw Taras and Ryszard Brykowski [12], we can assume that the fence was made of brick. From the photo (Fig. 13) we even read the brick thread - in the order the head and cart layers, which proves the authenticity of the wall from the 17th century. An interesting thing is an entrance to the church from the north shown in the photo. Standard solutions provide for the arrangement of the entrance to the church from the west and rarely from the south, never from the north. Violation of this rule was caused by the need to connect the entrance to the church with the pre-palace esplanade. 


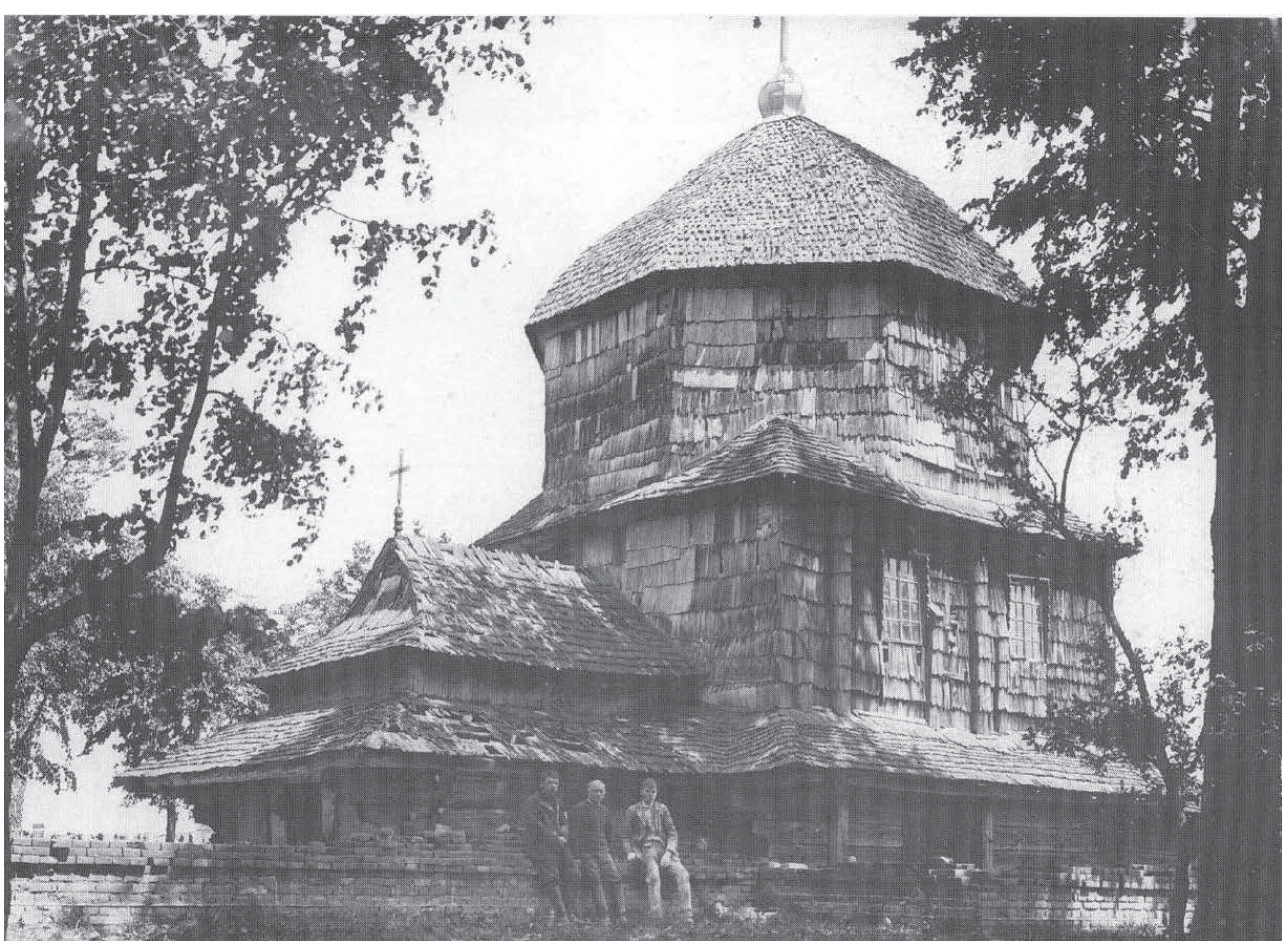

Fig. 13. The Greek Catholic Church of st. Mykola from 1708 in Kukizów. Photo from the beginning of 20 century (the holdings of the Museum of Ethnography in Lviv [12, p. 165])

The entrance gate to the royal residence was to be located on the longitudinal axis of the rectangular esplanade, laid out between the downtown and the palace complex. The gate axis from the opposite side of the square visually closed on the main facade of the church. When the residence was still there, all the buildings on the esplanade square were wooden - a Catholic church, a Greek Catholic church (Fig. 13) and residential buildings (fig. 14). Roofs and other finials had shingle roofs. It is known from the documents that the king went to the forest with the architect, to choose wood for the construction of the gate [21, p. 187]. We can conclude that the architecture of the gate also had elements in a wooden structure. Behind the gate was a small pre-palace square, framed on two sides with symmetrical wooden chancellery and kitchen buildings. The gate axis "closed" on the six-column portico of the palace.

\subsection{Reconstruction of town planning}

The town square was built up with wooden buildings according to the one pattern [3, p. 113-115]. In the center of the square, a wooden town hall building with beautiful architecture was erected.

The entire downtown urban complex with the buildings of residents (Ruthenians, Poles, and Karaites), town hall, kenasa, church and orthodox church was connected to the complex of buildings of the royal residence - a palace with a large, beautiful, orderly, two-part garden, office buildings and kitchens - all in wooden construction. Together, they created an urban complex of a city residence, unique to Poland and abroad. It is believed that the complex created in Kukizów was also unique due to the accepted compositional and urban principles as a town-baroque residence. 

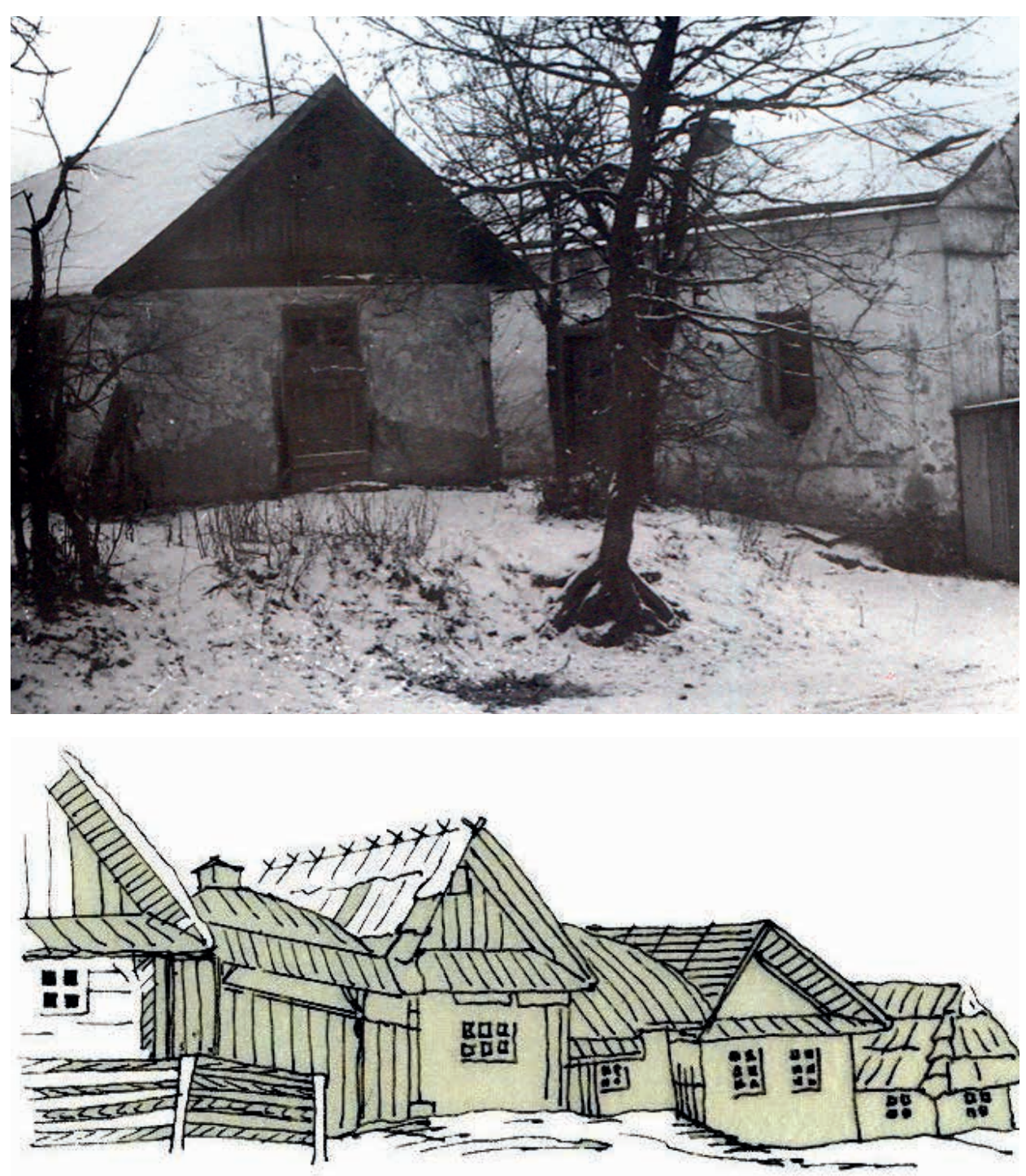

Fig. 16. A - The old buildings in the northern frontage of Rynek square in Kukizów.

Photo by Mycola Bevz, 1986

B - The old buildings of Rynek square in Kukizów, the beginning of 20 century.

Drawing by A.Hrechylo, from the book of A.Persowski [31]

Cadastral maps, although younger than Mieg's maps, complement our knowledge of the residence complex. The oldest cadastral map is dated to 1854 (Fig. 8) [36]. The palace and some of the residence buildings no longer existed. The map accuracy and precision in the presentation of details made it possible to read on it the remains of ancient fortification lines - two bastions with rounded ears (presumably Italian-style, which can be an additional argument for the authorship of the design of Augustyn Locci), connected to a partially preserved network of moats and water channels from the lifetime of the residence. Noteworthy are two 
artificial water channels framing the garden from the south and north. Undoubtedly, they formed the boundary of the complex, and their form indicates a connection with two bastions in the eastern part of the residence. According to the author's hypothesis, these bastions did not have a defensive function, but they were a standard decoration of the royal palace. The cadastral map confirms the asymmetry of the garden composition with respect to the main axis of the entire assumption (this also results from the map of F. von Mieg).

On the cadastral map small remains of the park are noticeable: two green side quarters are presented, but without one-story compositions with flowerbeds. The central, rectangular part of the pre-palace lawn has been preserved, from which the main avenue begins (indicating the course of the compositional axis of the former assumption). This avenue began in the round form of the square with accompanying, diagonally running, two side avenues (Fig. 6, 12).

The planning details discovered on the maps have been adapted to reconstruct the plan of the entire assumption (Fig. 11 and 12). The justification for this scheme is given below.

The location of the palace can be hypothetically drawn on a cadastral map, between two main alleys, along the axis of the round square and the central lawn, along the axis of the alley entering the forest. We can assume the width of the palace, remembering that the side elevations of the garden facade descended into the garden (this information from the inventory of 1741 was highlighted in the publication of J. Kowalczyk and presented on his reconstruction of the palace plan). It seems logical that the aforementioned stairs from the palace were oriented on two side alleys (Fig. 6, 10 and 12). The combined diagram of the two avenues on the cadastral map indicates that the distance in the axes between them is about $30 \mathrm{~m}$. Based on the palace plan reconstructions of Jerzy Kowalczyk, we can assume that the length of the palace was about 40-42 m. It should be assumed that the width in the projection section was about $14 \mathrm{~m}$. The palace building of this size presented on our planning reconstruction of the complex (Fig. 6, 12). The reconstructed plan also took into account the existence of a small square with chancellery and kitchen buildings between the gate, church, and palace. The location of the facilities and the planning layout of the square are obtained from the data of the map of F. von Mieg and the cadastral map.

The first mention of the existence of a church in Kukizów refers to 1560. It is the author's opinion that, during the creation of the residence, a new church building in the Baroque style was also built (photo on Fig. 13). The catholic church in wooden frame construction, like the orthodox church, had façades in the Baroque style. The late transmission says about the foundation of a new church dedicated to Saint Stanisław in 1668 by Mikołaj Giedziński, which was to be burned by the Tartars. In 1730 another wooden church was erected in Kukizów, dedicated to Saint James the Apostle, from the foundation of Prince Jakub Ludwik Sobieski [19].

In the 17th century the Market Square was called the Karaim Market. We know about the invitation of the Karaims by John III Sobieski [31, p. 46]. After 1831, they moved from Kukizów to Halycz [34, p. 854]. The mill in the southern part of the city existed from the beginning of the city's history.

\section{Conclusions}

The main conclusions from the presented research are as follows:

- In Kukizów in earlier times, before the palace complex was founded by John III Sobieski in the 1680 s, there were two fortified mansions (castles): The older one 
was located at a distance west of the city, on an island, in the middle of the swampy valley of the Dumna River and Remenowski Stream (remnants of wall foundations with fragments of the Gothic bricks, traces of embankment and moat in the form of a circle; it was a building from around the 15th and 16th centuries). The second castle, on a rectangular plan with semicircular bastions in the corners (founded probably in the 16th century), was located on the bank of the pond, southwest of the town center and was connected with city ramparts.

- The residence with the palace of John III Sobieski was built in a new place, irrespective of the previous two castles, in the western part of the urban settlement, on the extension of the street running from the northwest corner of the market square.

- The palace complex of John III Sobieski was surrounded by a bastion line of fortifications, the traces of which are still legible on historical cartographic materials from the late 18th and mid-19th centuries. This allows us to perform a graphic reconstruction of the planning structure of the object. Answers to the question about the functions of the bastion line: to what extent was it military or only ceremonial, should be sought in future studies.

- The park and garden part of the complex consisted of five main buildings: 1. a palace square from the city side (combined with the church and orthodox church buildings); 2. a one-story garden adjacent to the west facade of the palace; 3 . a regular housing garden on subsequent park terraces; 4 . the forest and park part, running west, on the continuation of the main axis of the residence; 5. a small hunting castle on the island, adapted to new needs, in the middle of the pond.

- Downtown and the palace-park complex, including the woods, were located on a conventional island, surrounded by water from all sides: from the south and west by ponds, and in the east and north - by the bank of the river.

- The planning scheme of the residence, garden, and town complex shows the author's professional qualifications and his great experience in designing urban compositions. In our opinion, the complex concept belongs to an Italian school. The question of whether it is the urban composition of the object by Tylman of Gameren (the general scheme of the assumption resembles essentially his plan of residence in Przecław, designed for the Rej), or the palace architect - Augustyn Winsente Locci, or its builder - Piotr Beber, remains unresolved, but does not seem particularly important: probably all of the mentioned persons, including John III Sobieski, took part in the creation of the residence.

- The analyzed palace and park complex in Kukizów, as well as the entire town, require further thorough archival and field research.

- The urban complex of the royal residence in Kukizów - an outstanding and littleknown work of Baroque architecture, was one of the greatest examples of wooden architecture of the 17th century in Poland and Europe.

The residence in Kukizów was a charming rural residence, corresponding to the 17th-century ideals of life, according to which summer holidays had to be spent in a quiet place where there was no rigid etiquette and life seemed simpler. The image of the reconstruction of these assumptions justifies the new name of Kukizów - Krasny Ostrów, created after the implementation of John III Sobieski foundation.

The implementation of the complex of the royal residence and the city in the form of a wooden architecture presents an unique experiment in the space of Baroque architecture in Europe, where dominate exuberant, rich stucco decorations of artificial stone, fanciful 
forms of buildings separated by rustication, projections, belts of multiple cornices and pilasters. Wooden material was also the most suitable for receiving forms of the imposing baroque architecture.

\section{References}

[1] Aftanazy R., Dzieje rezydencji na kresach dawnej Rzeczypospolitej. - Warszawa: Ossoloineum, 1999. - T. 7.

[2] Archive of the Department of Architecture and Conservation, Lviv Polytechnic National University: Bevz, Mykola, Materials of field survey of the old castle in Kukizów-Leshchiw, sygn. 2016-PM01, p. 1-8.

[3] AGZ. - T. I. - Warszawa: 1868. - S. 113-115. (przywilej z 1699 p.) [in] http://www.europeana. eu/portal/record/92033/Bibliographic Resource_3000053548350.html [Access: 19 Dec 2018]

[4] AGZ. - T. X. - Warszawa: 1884. - S. 213. Dokument erekcyjny kościoła w Żółkwi. Available: http://www.europeana.eu/portal/record/92033/Bibliographic Resource_3000053548350.html [Access: 19 Dec 2018]

[5] AGZ. - T. XIV. Najdawniiejsze zapiski sądỏw lwowskich. 1440-1456. - Warszawa: 1889. S. 19 (dok. 137). Available: http://www.europeana.eu/portal/record/92033/Bibliographic Resource_3000053548350.html [Access 19.12.2018].

[6] Aleksandrowycz W., "Ukrajinski malarii pracijuczi na dwori Jana III Sobieskoho", in: Chronika 2000. - Ukrajina-Polszcza: dialog uprpdowz tysiaczolit. Kyiv, 2012, pp. 17-151.

[7] Balaban M. "Karaici”, in: Studia historyczne w Polsce. pp. 26-28.

[8] Baliński M., Lipiński T. Starożytna Polska pod wzgłędem historycznym, geograficznym i statystycznym opisana. Warszawa, 1845. pp. 606-607.

[9] Baskakov N.A., Zajączkowski A., Šapšal S.M. Karaimsko-russko-polskiy slovar'. Moskva, 1974, pp. 336-337.

[10] Bevz M., "Problemy reheneratsiyi zapovidnykh terytoriy istorychnykh mist", Visnyk Natsionalnoho Universytetu „Lvivska politechnika“. Arkhitektura. L'viv, 2001. №429, pp. 146-155.

[11] Bevz M. "Palac krolewski Jana III Sobieskiego w Kukizowie: proba rekonstrukcji urbanistyczno-krajobrazowej”, in: Wladza i architektura. Rezydencje monarchow i siedziby wladz panstwowych w Europie - formy i funkcjie (XV-XXI w.), Materials of the 1st PRE international scientific conference in the Royal Castle in Warsaw, 9-11 April 2014, ed. Anna Czarniecka, Przemyslaw Deles, Angela Soltys, Zamek Krolewski w Warszawie-Muzeum, pp. 261-281.

[12] Brykowski R. Cerkwie drewniane na kresach. Warszawa, 2001. pp. 77.

[13] Gębarowicz M. Szkice z historii sztuki XVII wieku. Chapter 3: Pałac w Kukizowie. Toruń: 1966. pp. 231-245.

[14] Janusz B., "Karaici i ich cmentarzysko w Kukizowie“, Ziemia, 1911, vol. 11, p. 3.

[15] Cadastral Maps and Landowner Records from Kukizow. Avaialble: http://www.geshergalicia.org/ towns/kukizow. [Access: 20 Sep 2019]

[16] Cracovia Leopolis, DUBLANY / JAMNA / JAREMCZE / KUKIZÓW / SOKAL / WOROCHTA. Available: http://www.cracovia-leopolis.pl/index.php?pokaz=art\&id=1499 [Access: 21 Apr 2015]

[17] Wikipedia.org, Jan III Sobieski. Available: https://pl.wikipedia.org/wiki/Jan_III_Sobieski [Access: 10 Mar 2020]

[18] Wikipedia.org Kukizów. Available: https://pl.wikipedia.org/wiki/Kukiz\%C3\%B3w [Access: 20 Apr 2019] 
[19] Kościół parafialny pod wezwaniem Św. Jakuba Apostoła w Kukizowie. Available: http://www. rkc-skowyra.com/publ/7-205-2//Dekanat Żółkiew [Access: 20 Sep 2019]

[20] Szlak Sobieskiego. Available: http://szlaksobieskiego.pl/publikacje/1/1.pdf [Access: 20 Apr 2015]

[21] Kowalczyk J., "Pałac Jana III w Kukizowie: Piotr Beber czy Augustyn Locci?”, Arx Felicitatis, 2001, pp. 183-189.

[22] Kriegsarchiv Wien. H 76-133, F. Mapa 1890 r. Galicya.

[23] Kuśnierz K. Sieniawa. Krakow, 1999. p. 114.

[24] Mańkowski T., “Mecenat Jana III w Żółkwi”, Prace Komisii Historii Sztuki, 1948. pp. 133-138.

[25] Galizien und Lodomerien (1779-1783) - First Military Survey, Available: https://mapire.eu/en/ map/firstsurvey-galicia/?layers=144\&bbox [Access: 20 Apr 2019]

[26] F. Von Mieg map. Osterraichisches Staatsarchiv. Kriegsarchiv. Sygn. B IX A, ark. 265.

[27] Milobędzki A., Architektura Polska XVII wieku. PWN, 1980. p. 397.

[28] Mossakowski S., Tylman z Gameren.Architekt polskiego baroku. Wroclaw, Warszawa, Kraków, Gdańsk: Zakład Narodowy imienia Ossolińskich, 1973. 350 s.

[29] Mychailo P., Pamijatajemo tebe. Meminimus Tui. Z istorii Kukezowa. Lviv, 2014, pp. 77-108.

[30] Gębarowicz M. „Opisanie pałacu Kukizowskiego die 24 Juni 1741 Anno. Inwentarz pałacu, ogrodu, folwarku i ratusza w Kukizowie z archiwum Jana Tarły” in: Szkice z historii sztuki XVII wieku. Chapter 3. Torun: 1966, pp. 236-245.

[31] Persowski F., Osady na prawie russkiemu, wołoskiemu i niemieckim w ziemi Lwowskiej. Lwów, 1924, p. 46.

[32] Petryszyn H., Karta F. von Miega" (1779 -1782) jak dzerelo do mistoznavstwa Halyczyny. Lviv Wydawnyctwo Nacionalnoho uniwersytetu "Lwiwska Politechnika", 200, p. 290.

[33] Uruski S., Rodzina. Herbarz szlachty polskiej. Vol. VIII, 1911, p. 176.

[34] Sulimierski F., Chlebowski B., Walewski W., Słownik Geograficzny Królestwa Polskiego i innych krajów słowiańskich. Warszawa, 1883, vol. IV, p. 854.

[35] Swesznikow I.K., Dowidnyk z archeologii Ukrainy. Lwiwska oblast. Naukowa dumka, Kyiv, 1976, p. 56.

[36] Kukyziv, kadastrova karta, 1854 r., ark. 3, 5, 7, 8. Tsentralnyj derzhawnyj istorycznyi archiw Ukrainy w misti Lwowi, fond 186, opys 5, spr. 330.

[37] Kukyziv, kadastrova karta, 1870 r., ark. 8. Tsentralnyj derzhawnyj istorycznyi archiw Ukrainy w mistiLwowi, fond 186, opys 5, spr. 331 .

[38] Kukyziv, kadastrova karta, 1927 r., ark. 3, 5, 7,8. Tsentralnyj derzhawnyj istorycznyi archiw Ukrainy w misti Lwowi, fond 186, opys 5, spr. 335.

[39] Kukyziv, karta 1890 r. - ark. 44, (1440). Tsentralnyj derżawnyj istorycznyi archiw Ukrainy w misti Lwowi, fond 9, opys 1, spr. 1.

[40] Wojcik Z., Jan Sobieski: 1629-1696. PIW, Warszawa 1983.

[41] Zdybel B., „Kukyziw jakyj ja znaju I jakyj ja czula”, in: MychailoPadura. Pamijatajemo tebe. Meminimus Tui. Z istorii Kukezowa. Lviv, 2014, pp. 500-505. 